\title{
Genetic Diversity of Daphnia pulex in the Middle and Lower Reaches of the Yangtze River
}

\author{
Wenping Wang, Kun Zhang, Daogui Deng*, Ya-Nan Zhang, Shuixiu Peng, Xiaoxue Xu \\ School of Life Science, Huaibei Normal University, Anhui Key Laboratory of Resource and Plant Biology, \\ Huaibei, 235000, China \\ * dengdg@263.net
}

\section{Abstract}

Increased human activities and environmental changes may lead to genetic diversity variations of Cladocerans in water. Daphnia pulex are distributed throughout the world and often regarded as a model organism. The $16 \mathrm{~S}$ rDNA, cytochrome $\mathrm{c}$ oxidase subunit I (COI), and $18 S$ genes were used as molecular marks. The genetic diversity and phylogeny of $D$. pulex obtained from 10 water bodies in the middle and lower reaches of the Yangtze River were studied. For $16 \mathrm{~S}$ rDNA, COI gene, and $18 \mathrm{~S}$ gene, the A+T content $(65.4 \%, 58.4 \%$, and $54.6 \%$ ) was significantly higher than the $\mathrm{G}+\mathrm{C}$ content $(34.6 \%, 41.6 \%$ and $45.4 \%)$. This result was consistent with higher $A$ and $T$ contents among invertebrates. Based on the genetic distances of $16 S$ rDNA and COI genes, the genetic differences of $D$. pulex from 10 water bodies located in the middle and lower reaches of the Yangtze River in China was minimal ( $0 \%-0.8 \%$ for $16 S$ rDNA and $0 \%-1.5 \%$ for COI gene). However, D. pulex evolved into two branches in the phylogenetic trees, which coincided with its geographical distribution. Compared with $D$. pulex from other countries, the average genetic distance of $D$. pulex obtained from 10 water bodies in the middle and lower reaches of the Yangtze River reached $9.1 \%-10.5 \%$, thereby indicating that $D$. pulex may have evolved into different subspecies.

\section{Introduction}

Cladocerans are important components of the food chain in aquatic ecosystems [1]. First, these organisms can feed on algae and improve water quality [2-4]. Second, cladocerans are predated by fish as food. Cladocerans undergo parthenogenesis in suitable environments and form large populations. However, sexual reproduction of Cladocerans occurs under bad conditions and fertilized eggs are produced. Daphnia pulex is a cosmopolitan species that is widely distributed in inland fresh waters, particularly in eutrophic waters [5-6]. To date, frequent human activities have led to environmental differences among lakes, such as variations in nitrogen and phosphorus concentrations in the sediment in the middle and lower reaches of the Yangtze River [7]. Eutrophication and the structure of the fish population may also have affected the population dynamics of D. pulex in these lakes [8-10]. 
Multiple methods are available for species identification and phylogeny reconstruction of crustaceans [11-15]. The $16 \mathrm{~S}$ rDNA and the cytochrome $c$ oxidase subunit I (COI) and $18 \mathrm{~S}$ genes are more popular among these methods [15-21]. The classification of 16S rRNA and COI gene sequences were more convincing in Daphnia. The mitochondrial divergences of different Daphnia species are below 5\% between North and South America [22-24] and between North America and Europe [25].

John et al. (2011) reported the gene sequences of $D$. pulex [26]. A few functional genes of crustaceans were widely studied [16, 20, 26-28]. Benzie (2005) described the D. pulex complex, including $D$. pulex, D. pulicaria, and D. middendorffiana [6]. The different $D$. pulex complexes are distributed worldwide, and the species was studied as a model by many investigators [2832]. Ceresa et al. (2012) investigated the intercontinental phylogeography of the D. pulex complex by analyzing the mitochondrial NADA dehydrogenase subunit 5 and the COI gene [29]. Some works in the literature showed that the genetic distance ranged from $5 \%$ to $14 \%$ for $D$. pulex complex $[16,29,33]$. Although the molecular phylogeny of $D$. pulex was extensively reported, the genetic differences of the $D$. pulex from China and comparison of species in China and those in other countries have not been reported.

In this study, the genetic difference among the $D$. pulex from 10 water bodies located in the middle and lower reaches of the Yangtze River and the genetic difference of the D. pulex between China and other countries were analyzed by amplifying and sequencing the $16 \mathrm{~S}$ rDNA, as well as the COI and $18 \mathrm{~S}$ genes. Our results could become an important evidence for the global phyletic evolution of $D$. pulex.

\section{Materials and Methods}

\section{Sampling, identification and culturing}

Field collection of Daphnia was carried out after obtaining permission from the Ministry of Environment, and the field studies did not include endangered or protected species.

The fertilized eggs of $D$. pulex were collected from the sediment of 10 water bodies located in the middle and lower reaches of the Yangtze River with a modified Peterson grab (Table 1). The eggs were hatched in an intelligent lighting incubator (Ningbo Saifu, China) at $25^{\circ} \mathrm{C} . D$. pulex was identified morphologically (Fig 1) under the microscope (Olympus, Japan) according

Table 1. Origin and number of $D$. pulex species in this study.

\begin{tabular}{|c|c|c|c|c|}
\hline \multirow[t]{2}{*}{ Locality } & \multirow[t]{2}{*}{ Longitude and latitude } & \multicolumn{3}{|c|}{ Collection catalog numbers } \\
\hline & & $16 S$ & $\mathrm{COI}$ & $18 S$ \\
\hline Donghu Lake, Hubei province & $\mathrm{N}: 30^{\circ} 32^{\prime} 46.04^{\prime \prime} \mathrm{E}: 114^{\circ} 22^{\prime} 31.20^{\prime \prime}$ & WD1WD2WD3 & WD1WD2WD3 & WD \\
\hline Guohe River, Anhui province & $\mathrm{N}: 33^{\circ} 52^{\prime} 37.25^{\prime \prime} \mathrm{E}: 115^{\circ} 47^{\prime} 27.00^{\prime \prime}$ & BZ1BZ2 & BZ1BZ2 & $\mathrm{BZ}$ \\
\hline Qianlong Lake, Anhui province & $\mathrm{N}: 33^{\circ} 54^{\prime} 21.49^{\prime \prime} \mathrm{E}: 116^{\circ} 48^{\prime} 55.27^{\prime \prime}$ & QL & QL1QL2QL3 & QL \\
\hline Pond in Anhui province & $\mathrm{N}: 33^{\circ} 38^{\prime} 59.33^{\prime \prime} \mathrm{E}: 116^{\circ} 57^{\prime} 35.21^{\prime \prime}$ & SZ & SZ1 SZ2 & SZ \\
\hline Shengjin Lake, Anhui province & $\mathrm{N}: 30^{\circ} 21^{\prime} 0.10^{\prime \prime} \mathrm{E}: 117^{\circ} 0^{\prime} 36.30^{\prime \prime}$ & SJ1 SJ2 & SJ & SJ \\
\hline Chaohu Lake, Anhui province & $\mathrm{N}: 31^{\circ} 33^{\prime} 28.74^{\prime \prime} \mathrm{E}: 117^{\circ} 0^{\prime} 36.30^{\prime \prime}$ & $\mathrm{CH}$ & $\mathrm{CH}$ & $\mathrm{CH} 1 \mathrm{CH} 2 \mathrm{CH} 3$ \\
\hline Nanyi Lake, Anhui province & $\mathrm{N}: 31^{\circ} 4^{\prime} 27.11^{\prime \prime} \mathrm{E}: 118^{\circ} 58^{\prime} 40.64^{\prime \prime}$ & XC1XC2XC3XC4 & XC1XC2XC3XC4 & $\mathrm{XC}$ \\
\hline Taihu Lake, Jiangsu province & $\mathrm{N}: 31^{\circ} 29^{\prime} 9.29^{\prime \prime} \mathrm{E}: 120^{\circ} 11^{\prime} 43.70^{\prime \prime}$ & $\mathrm{TZ}$ & $\mathrm{TZ}$ & $\mathrm{TZ}$ \\
\hline Hongze Lake, Jiangsu province & $\mathrm{N}: 33^{\circ} 17^{\prime} 48.74^{\prime \prime} \mathrm{E}: 118^{\circ} 39^{\prime} 44.37^{\prime \prime}$ & $\mathrm{HZ1HZ2}$ & $\mathrm{HZ}$ & $\mathrm{HZ}$ \\
\hline Pond in Shanghai city & $\mathrm{N}: 31^{\circ} 13^{\prime} 48.02^{\prime \prime} \mathrm{E}: 121^{\circ} 24^{\prime} 16.20^{\prime \prime}$ & $\mathrm{SH} 1 \mathrm{SH} 2$ & $\mathrm{SH} 1 \mathrm{SH} 2 \mathrm{SH} 3$ & $\mathrm{SH}$ \\
\hline
\end{tabular}

Note: Four different individuals were collected from each waterbody, but only one individual was chosen for each sequence. $\mathrm{N}$ indicates the North latitude, and $\mathrm{E}$ indicates East longitude.

doi:10.1371/journal.pone.0152436.t001 


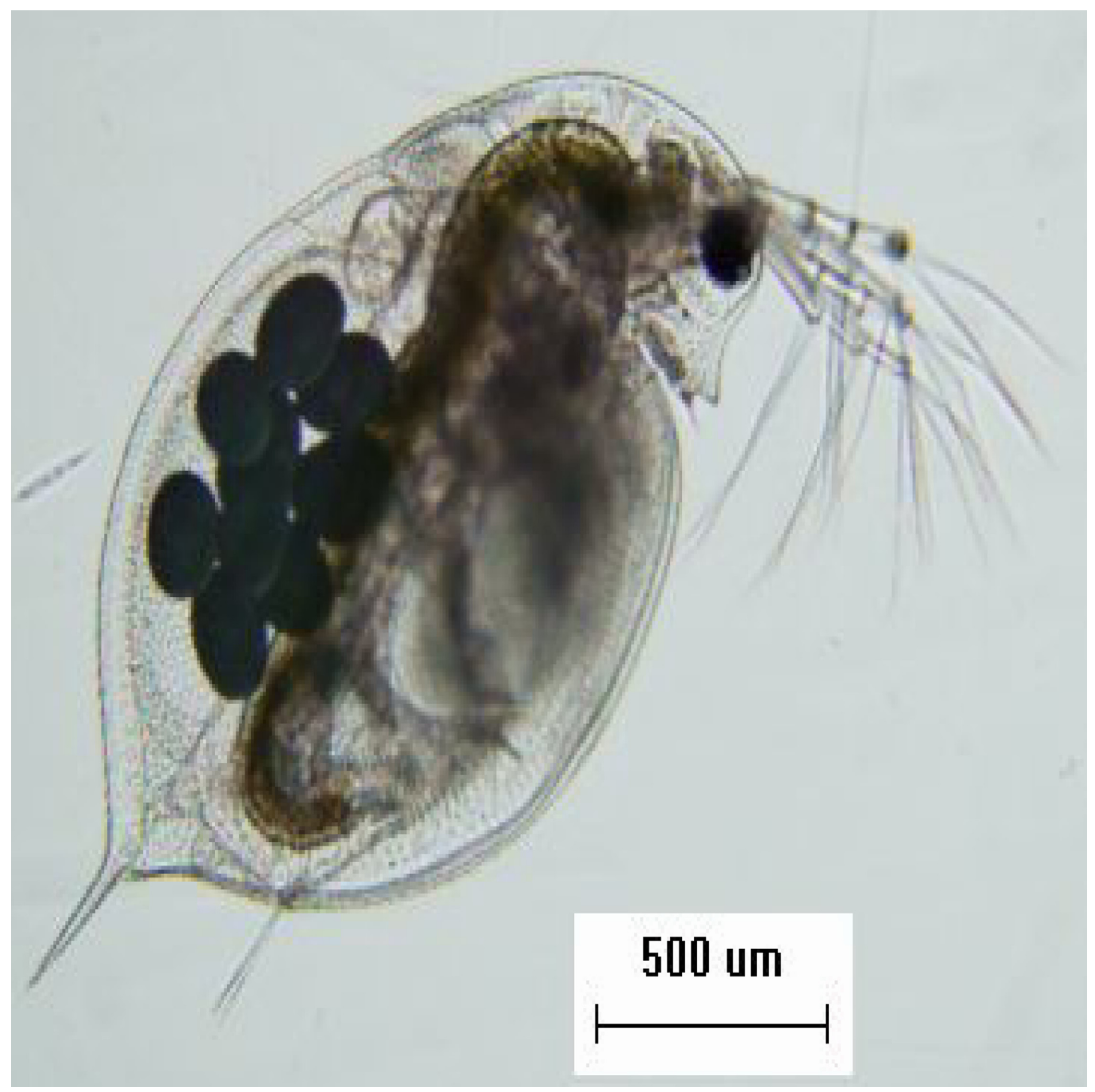

Fig 1. The photograph of adult $D$. pulex female.

doi:10.1371/journal.pone.0152436.g001

to the methods of Jiang and Du [5] and Benzie [6]. For each water body, four individuals of $D$. pulex were selected by hatching different fertilized eggs. Monoclonal organisms were cultured in an intelligent light incubator (Ningbo Saifu, China) with $12 \mathrm{~h}$ light:12 $\mathrm{h}$ dark illumination at 
$25^{\circ} \mathrm{C}$. Scenedesmus obliquus was used as their food. The medium was aerated tap water over 48 $\mathrm{h}$, and $\mathrm{pH}$ was approximately 7 .

\section{DNA extraction, amplification, and sequencing}

Young $D$. pulex hatched from the fertilized eggs became adults and became pregnant after roughly 7 days at $25^{\circ} \mathrm{C}$. An adult individual was selected. Genomic DNA of D. pulex was extracted by the TIANamp Micro DNA Kit (Tiangen, Beijing). Each D. pulex body was crushed with a sterile $10 \mu \mathrm{L}$ tip before extraction because the chitin carapace of $D$. pulex could hinder the digestion of internal organs by proteinase $K$. The concentration of DNA extraction was measured by the Spectrophotometer (Biofuture, England). The concentrations of DNA were $65-85 \mathrm{ng} / \mu \mathrm{L}$ and the A280/A260 was 2.3.

The mitochondrial $16 S$ rDNA was amplified with the L2510 (5'-CGCCTGTTTAAC AAAAACAT- $3^{\prime}$ ) and H3059 (5'-CCGGTCTGAACTCAGATCATGT-3') primers [34]. The mitochondrial COI gene was amplified with the COIF ( $5^{\prime}$-AYCAATCATAAGGACYATTGG RAC-3 ${ }^{\prime}$ ) and COIR (5'-KGTGATWCCNACHGCTCAKAC- $\left.3^{\prime}\right)$ primers from Xu et al. [35]. The nuclear $18 S$ gene was amplified with the $18 S$-F (5'-AACCTGGTTGATCCTGCCAGT-3') and $18 S-\mathrm{R}\left(5^{\prime}\right.$-TGATCCTTCTGCAGGTTCACCTAC-3') primers from Huang et al. [19].

To validate the predicted sequences of chemosensory genes, the PCR (Eppendorff, Germany) products obtained from genomic DNA of adult $D$. pulex were purified using the AxyPrep TM PCR Cleanup Kit (Axygen) and sub-cloned into a T/A plasmid using the pEASY-T3 cloning vector system (TransGen, China) following the manufacturer's instructions. The plasmid DNA was used to transform to Trans1-T1 competent cells. The positive clones were checked by PCR and sequenced by GenScript (Nanjing, China).

The $25 \mu \mathrm{L}$ PCR reaction contained 1.0 $\mu \mathrm{L}$ of genomic DNA, $14.75 \mu \mathrm{L}$ of double-distilled $\mathrm{H}_{2} \mathrm{O}, 2.5 \mu \mathrm{L}$ of $10 \times$ LA-Taq Buffer II, $4.0 \mu \mathrm{L}$ of dNTPs $(2.5 \mathrm{mM}$ ) (Shanghai Shenggong, China), $0.5 \mu \mathrm{L}$ of $\mathrm{Mg}^{2+}(25 \mathrm{mM}), 1.0 \mu \mathrm{L}$ of each primer $(10 \mathrm{mM}$ ) (Shanghai Shenggong, China), and $0.25 \mu \mathrm{L}$ of DNA polymerase TaKaRa-LA-Taq $(5 \mathrm{U} / \mu \mathrm{L})$ (Clontech, USA).

The conditions of the $16 \mathrm{~S}$ rDNA amplification included an initial denaturing step of $3 \mathrm{~min}$ at $94^{\circ} \mathrm{C}, 35$ cycles of $45 \mathrm{~s}$ at $94^{\circ} \mathrm{C}, 45 \mathrm{~s}$ at $50^{\circ} \mathrm{C}$, and $55 \mathrm{~s}$ at $72^{\circ} \mathrm{C}$, and a final extension of $72^{\circ} \mathrm{C}$ for $10 \mathrm{~min}$. The conditions of the $\mathrm{COI}$ gene amplification included an initial denaturing step of $1 \mathrm{~min}$ at $94^{\circ} \mathrm{C}, 35 \mathrm{cycles}$ of $40 \mathrm{~s}$ at $94^{\circ} \mathrm{C}, 40 \mathrm{~s}$ at $45^{\circ} \mathrm{C}$, and $1 \mathrm{~min}$ at $72^{\circ} \mathrm{C}$, and a final extension of $72^{\circ} \mathrm{C}$ for $10 \mathrm{~min}$. The conditions of the $18 \mathrm{~S}$ gene amplification included two cycles of $30 \mathrm{~s}$ at $94^{\circ} \mathrm{C}, 45 \mathrm{~s}$ at $60^{\circ} \mathrm{C}$, and $45 \mathrm{~s}$ at $72^{\circ} \mathrm{C}$, followed by five cycles of $30 \mathrm{~s}$ at $93^{\circ} \mathrm{C}, 45 \mathrm{~s}$ at $55^{\circ} \mathrm{C}$, and 45 s at $72^{\circ} \mathrm{C}$, and a final $35 \mathrm{cycles}$ of $30 \mathrm{~s}$ at $93^{\circ} \mathrm{C}, 30 \mathrm{~s}$ at $50^{\circ} \mathrm{C}$, and $3 \mathrm{~min}$ at $72^{\circ} \mathrm{C}$.

\section{Analytical procedure}

According to the peak in SeqMan, the bidirectional sequencing of the nucleotide sequence was proofread by DNAStar to remove unreliable bases. The percentage of the detected sequence differences was obtained.

For each water body in the middle and lower reaches of Yangtze River, the sequences of the four $D$. pulex individuals were obtained. Unreliable bases were removed by SeqMan (DNAStar). A total of 517-539 valid bases for $16 \mathrm{~S}$ rDNA, 522-527 valid bases for the COI gene, and 2335-2344 valid bases for the $18 \mathrm{~S}$ genes were detected (Table 1). Other sequences that were used for analysis were downloaded from GenBank (Tables 2-4). In this study, the standard of the selected sequences was the similarity of the homologous sequence (over $80 \%$ ) compared with the sequences from Genbank.

Multiple sequence alignment was performed with CLUSTALX (ref.). DNAspV5 (ref.) was used to analyze the variation of sites among the sequences. The conversion/transversion and the 
Table 2. $16 S$ rDNA sequences of Daphnia and Bosmina from GenBank.

\begin{tabular}{|c|c|c|c|c|}
\hline Species & Code in the study & GenBank accession number & Collection location & Reference \\
\hline Daphnia pulex & KF64 & KF993364 & China & Xu et al. [35] \\
\hline D. pulex & KF63 & KF993363 & China & Xu et al. [35] \\
\hline D. pulex & $\mathrm{AF} 17$ & AF117817 & Canada & Crease et al. [40] \\
\hline D. pulex & JN07 & JN874607 & Russia & Zuykova et al. [42] \\
\hline D. pulex & JN06 & JN874606 & Russia & Zuykova et al. [42] \\
\hline D. pulex & JN05 & JN874605 & Russia & Zuykova et al. [42] \\
\hline D. pulex & GQ75 & GQ343275 & Canada & Briski et al. [41] \\
\hline D. parvula & GQ64 & GQ343264 & Canada & Briski et al. [41] \\
\hline D. parvula & GQ65 & GQ343265 & Canada & Briski et al. [41] \\
\hline D. parvula & GQ66 & GQ343266 & Canada & Briski et al. [41] \\
\hline D. parvula & GQ67 & GQ343267 & Canada & Briski et al. [41] \\
\hline D. parvula & GQ71 & GQ343271 & Canada & Briski et al. [41] \\
\hline D. parvula & FJ73 & FJ427473 & Canada & Adamowicz et al. [33] \\
\hline D. cf. parvula sp. & FJ74 & FJ427474 & Canada & Adamowicz et al. [33] \\
\hline D. obtusa group sp. & FJ71 & FJ427471 & Canada & Adamowicz et al. [33] \\
\hline D. obtusa & FJ66 & FJ427466 & Canada & Adamowicz et al. [33] \\
\hline D. obtusa group sp. & FJ70 & FJ427470 & Canada & Adamowicz et al. [33] \\
\hline D. obtusa group sp. & FJ67 & FJ427467 & Canada & Adamowicz et al. [33] \\
\hline D. magna & D. magna & AY921452 & USA & Colbourne et al. [46] \\
\hline Bosmina sp. & Bosmina & EU650743 & USA & Kotov et al. [18] \\
\hline
\end{tabular}

Note: D. pulex (GenBank accessions: KF993364 and KF993363) were obtained from Lake Chaohu in China.

doi:10.1371/journal.pone.0152436.t002

genetic distance of interspecies were calculated with MEGA 6.0 (ref.). The genetic distances among sequences were calculated by the Kimura two-parameter model with 1,000 bootstraps. The maximum likelihood (ML) analysis, which used the GTR+G+I evolutionary model indicated by Modeltest version 3.7, was performed with MEGA 6.0 (ref.) and bootstrap resampled 1,000 times. In addition, we constructed phylogenetic trees via Bayesian inference in MrBayes 3.1.2 (ref.). This program was run for 10,000,000 generations, and sampling from the chain was performed every 10,000 generations. Initially, $25 \%$ of the trees were discarded as burn-in, and the $50 \%$ majority rule consensus tree was constructed from the remaining Bayesian trees after the posterior probability values for each node were calculated. To better reveal the genetic difference of $D$. pulex, the suitable outgroups were employed to construct phylogenetic trees. For $16 \mathrm{~S}$

Table 3. COI gene sequences of Daphnia and Ceriodaphnia from GenBank.

\begin{tabular}{|c|c|c|c|c|}
\hline Species & Code in the study & GenBank accession & Collection location & Reference \\
\hline Daphnia. pulex & KJ74 & KJ461674 & China & Geng et al. [47] \\
\hline D. pulex & KF72 & KF993372 & China & Xu et al. [35] \\
\hline D. pulex & KF71 & KF993371 & China & Xu et al. [35] \\
\hline D. cf. pulex & GU92 & GU595192 & Japan & Kotov et al. [43] \\
\hline D. cf. pulex & GU90 & GU595190 & Japan & Kotov et al. [43] \\
\hline D. jollyi & D. jollyi & AF308969 & Canada & Hebert et al. (2000) \\
\hline Ceriodaphnia cf. reticulata & C.cf.reticulata & KC617252 & Mexico & Prosser et al. [48] \\
\hline
\end{tabular}

Note: D. pulex (GenBank accession: KJ461674, KF993372, and KF993371) were obtained from Lake Chaohu in China.

doi:10.1371/journal.pone.0152436.t003 
Table 4. $18 S$ gene sequences of Daphnia and Ceriodaphnia from GenBank.

\begin{tabular}{|c|c|c|c|c|}
\hline Species & Code in the study & GenBank accession & Collection location & Reference \\
\hline D. pulex & KJ027 & KJ775027 & China & Huang et al. [19] \\
\hline D. pulex & AF011 & AF014011 & Canada & Crease et al. (1997) \\
\hline D. obtusa & AY600 & AY887600 & Canada & McTaggart et al. [49] \\
\hline D. obtusa & AY601 & AY887601 & Canada & McTaggart et al. [49] \\
\hline D. obtusa & AY604 & AY887604 & Canada & McTaggart et al. [49] \\
\hline D. obtusa & AY608 & AY887608 & Canada & McTaggart et al. [49] \\
\hline D. obtusa & AY611 & AY887611 & Canada & McTaggart et al. [49] \\
\hline D. obtusa & AY612 & AY887612 & Canada & McTaggart et al. [49] \\
\hline D. obtusa & AY614 & AY887614 & Canada & McTaggart et al. [49] \\
\hline D. obtusa & AY624 & AY887624 & Canada & McTaggart et al. [49] \\
\hline D. obtusa & AY630 & AY887630 & Canada & McTaggart et al. [49] \\
\hline D. obtusa & AY642 & AY887642 & Canada & McTaggart et al. [49] \\
\hline D. obtusa & AY545 & AY887545 & Canada & McTaggart et al. [49] \\
\hline D. obtusa & AY547 & AY887547 & Canada & McTaggart et al. [49] \\
\hline D. obtusa & AY552 & AY887552 & Canada & McTaggart et al. [49] \\
\hline D. obtusa & AY562 & AY887562 & Canada & McTaggart et al. [49] \\
\hline D. obtusa & AY565 & AY887565 & Canada & McTaggart et al. [49] \\
\hline D. obtusa & AY568 & AY887568 & Canada & McTaggart et al. [49] \\
\hline D. obtusa & AY577 & AY887577 & Canada & McTaggart et al. [49] \\
\hline D. obtusa & AY578 & AY887578 & Canada & McTaggart et al. [49] \\
\hline D. obtusa & AY580 & AY887580 & Canada & McTaggart et al. [49] \\
\hline D. obtusa & AY582 & AY887582 & Canada & McTaggart et al. [49] \\
\hline D. obtusa & AY583 & AY887583 & Canada & McTaggart et al. [49] \\
\hline D. obtusa & AY598 & AY887598 & Canada & McTaggart et al. [49] \\
\hline D. magna & D. magna & AM490278 & Belgium & Van Damme et al. [50] \\
\hline Ceriodaphnia dubia & C. dubia & AF144208 & USA & Spears et al. [51] \\
\hline
\end{tabular}

Note: D. pulex (GenBank accession: KJ775027) was obtained from Zhejiang province in China.

doi:10.1371/journal.pone.0152436.t004

rDNA, D. magna (AY921452) and Bosmina sp. (EU650743) were used as outgroups. For COI gene, D. jollyi (AF308969) and Ceriodaphnia cf. reticulata (KC617252) were used as outgroups. For 18 S gene, D. magna (AM490278) and C. dubia (AF144208) were used as outgroups. Analysis of molecular variance (AMOVA) test was conducted by using Arlequin 3.5 [36].

\section{Results}

\section{Genetic diversity of $D$. pulex from the middle and lower reaches of Yangtze River based on 165 rDNA}

The alignment of the $3716 \mathrm{~S}$ rDNA sequences identified 403 conserved sites, including 334 invariable sites, 69 variable sites, 9 single sites, and 60 parsimony-informative sites. Among the $16 \mathrm{~S}$ rDNA sequences of the $D$. pulex from 10 water bodies located in the middle and lower reaches of Yangtze River, the average A, T/U, C, and G content was $32.6 \%, 32.8 \%$, $13.6 \%$, and $21.0 \%$, respectively. The $\mathrm{A}+\mathrm{T}$ content $(65.4 \%)$ was significantly higher than the $\mathrm{G}+\mathrm{C}$ content $(34.6 \%)$. The overall transition/transversion ratio was 1.09 . The genetic distances between sequences were calculated by the Kimura 2-parameter distance $(0 \%-9.8 \%)$ and maximum likelihood estimate $(0 \%-11.5 \%)$. The phylogenetic trees produced highly congruent tree topologies (Fig 2). The main divergences in the ML tree were in accordance with 


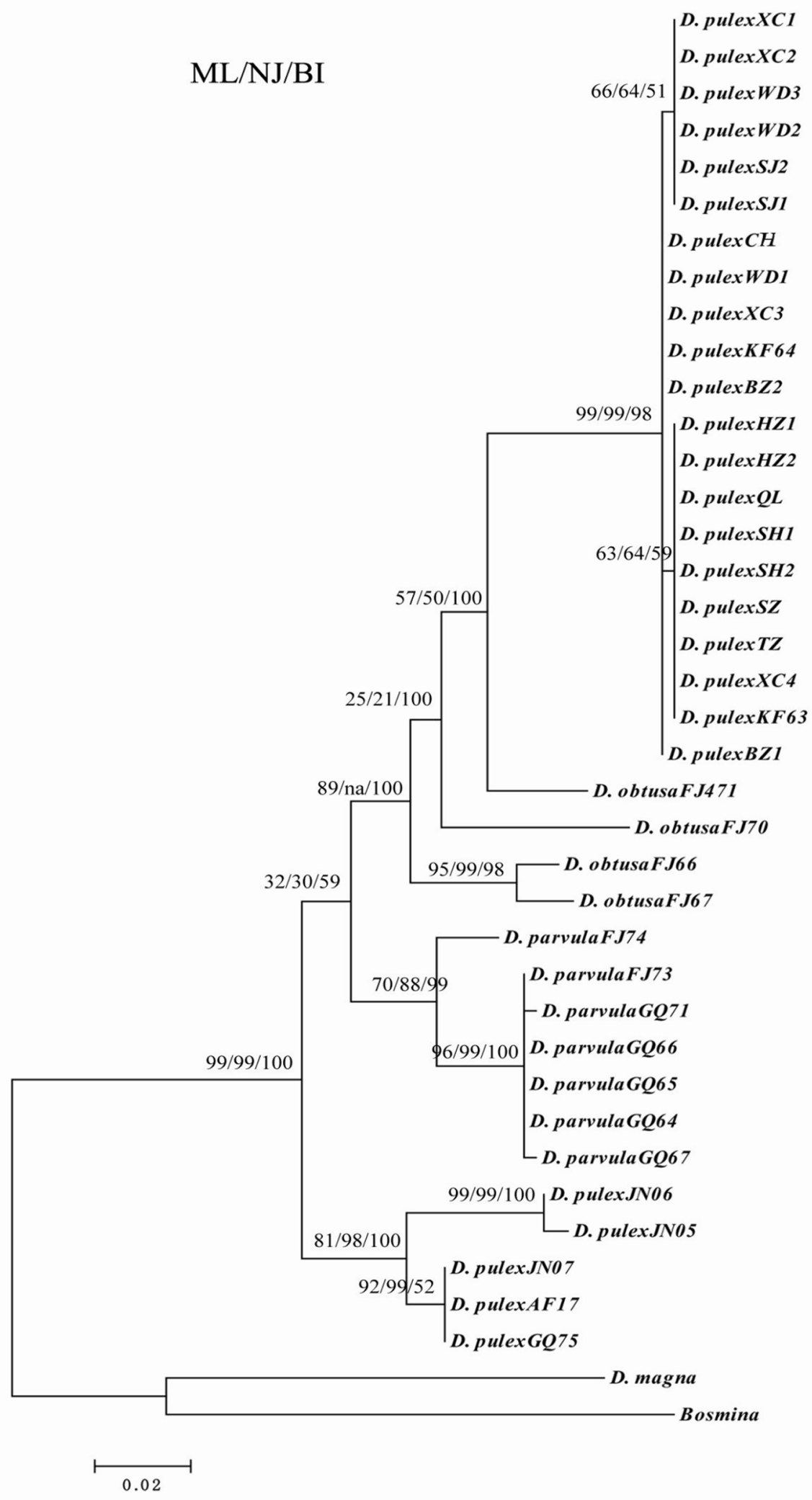

Fig 2. The phylogeny of $D$. pulex inferred from $16 S$ rDNA sequences as a consensus tree formed from trees constructed using maximum likelihood (ML), and neighbor-joining ( $\mathrm{NJ}$ ), Bayesian inference (BI) methods.

doi:10.1371/journal.pone.0152436.g002 
those of the MrBayes and NJ trees (Fig 2). In the phylogenetic trees, the branches represented $99 \%$ support for the presumed biological species of $D$. pulex. D. pulex from 10 water bodies located in the middle and lower of the Yangtze River evolved into two branches in the NJ tree. One branch included D. pulex from Lake Donghu in Hubei Province, as well as Lake Shengjin, Lake Nanyi, Lake Chaohu, and Guohe River in Anhui Province. The other branch included D. pulex from a pond in Shanghai City, Lake Taihu, and Lake Hongze in Jiangsu Province, as well as Lake Qianlong, a pond, Lake Chaohu, and Lake Nanyi in Anhui Province. $D$. pulex from Lake Chaohu and Lake Nanyi was present in both branches, which coincided with its geographical locations. In addition, the $D$. pulex from 10 water bodies located in the middle and lower reaches of the Yangtze River and the D. pulex from abroad were clustered in two distant branches (Fig 2).

\section{Genetic diversity of $D$. pulex from the middle and lower reaches of Yangtze River based on the COI gene}

The alignment of $26 \mathrm{COI}$ sequences identified 487 conserved sites, including 433 invariable sites, 54 variable sites, 9 single sites, and 45 parsimony-informative sites. Among the COI sequences of the $D$. pulex from 10 water bodies located in the middle and lower reaches of Yangtze River, the average A, T/U, C, and G content was $23.5 \%, 34.9 \%, 20.1 \%$, and $21.5 \%$, respectively. The $\mathrm{A}+\mathrm{T}$ content (58.4\%) was significantly higher than the $\mathrm{G}+\mathrm{C}$ content $(41.6 \%)$. The overall transition/transversion ratio was eight. The genetic distances between sequences were calculated by the Kimura two-parameter distance (0\%-11.3\%) and maximum likelihood estimate (0\%-11.4\%). The main divergence in the ML tree was in accordance with that of the MrBayes tree and NJ tree (Fig 3). In the phylogenetic trees, the branches represented 100\% support for the presumed biological species of $D$. pulex. The $D$. pulex from 10 water bodies located in the middle and lower reaches of Yangtze River diverged into two branches in the phylogenetic trees, which was consistent with the results of $16 \mathrm{~S}$ rDNA sequence analysis. In addition, the D. pulex (GU595190) from Japan and the D. pulex from 10 water bodies located in the middle and lower reaches of Yangtze River were evidently different, with an average genetic distance of $10.5 \%$.

\section{Genetic diversity of $D$. pulex from the middle and lower reaches of Yangtze River based on the $18 S$ gene}

The alignment results of $3618 S$ gene sequences identified 1963 conserved sites, including 1932 invariable sites, 31 variable sites, 20 single sites, and 11 parsimony-informative sites. Among the sequences of the $18 S$ gene for the $D$. pulex from 10 water bodies located in the middle and lower reaches of Yangtze River, the average A, T/U, C, and G contents were 20.5\%, 24.9\%, $24.3 \%$, and $30.3 \%$, respectively. The $\mathrm{A}+\mathrm{T}$ content $(54.6 \%)$ was significantly higher than the $\mathrm{G}+\mathrm{C}$ content (45.4\%). The overall transition/transversion ratio was 2.5 . The genetic distances between sequences were calculated by the Kimura two-parameter distance $(0 \%-2.0 \%)$ and the maximum likelihood ( $0 \%-1.3 \%)$. The main divergence in the ML tree was in accordance with that of the MrBayes and NJ trees. The phylogenetic trees produced highly congruent tree topologies (Fig 4). In the phylogenetic trees, the branches represented $99 \%$ support for a presumed biological species of $D$. pulex. The D. pulex from Lake Chaohu in Anhui province (CH3), Lake Hongze in Jiangsu province, Hangzhou City in Zhejiang province (KJ775027), and Canada (AF014011) belonged to the same branch, whereas smaller differences were observed with the other D. pulex individuals. The average genetic distance was $0.45 \%-0.64 \%$. 
$\mathrm{ML} / \mathrm{NJ} / \mathrm{BI}$

$97 / 100 / 100$

$80 / 100 / 80$

D. pulexHZ

D. pulexTZ

D. pulexGU92

D. pulexKF 71

D. pulexXC4

$70 / 79 / 80$ D. pulexXC3

$44 / 56 / 80$

D. pulex $B Z 2$

$65 / 85\left[59\left[\begin{array}{l}\text { D. pulexBZ1 } \\ \text { D. pulexKF } 72\end{array}\right.\right.$

D. pulexXC1

61/56/5 , D. pulexWD3

61 年 83

$56 / 54 / 83$

D. pulexWD1

-D. pulexSJ

D. pulexWD2

D. pulex XC2

D. pulexGU90

D. jollye

C. reticulata

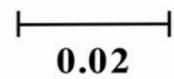

Fig 3. The phylogeny of $D$. pulex inferred from mitochondria cytochrome $c$ oxidase subunit I (COI) sequences as a consensus tree formed from trees constructed using maximum likelihood (ML), and neighbor-joining (NJ), Bayesian inference (BI) methods. 


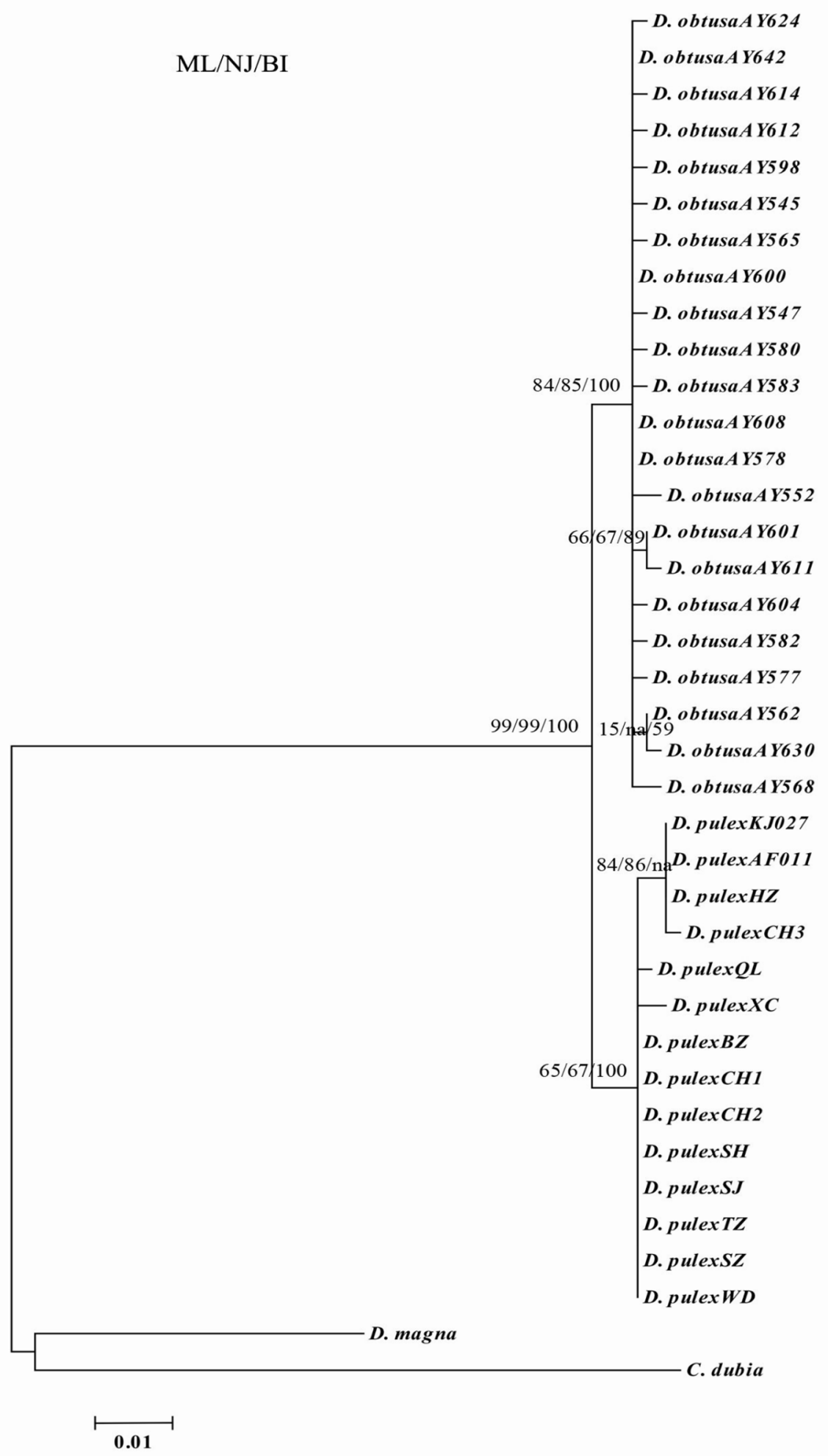

Fig 4. The phylogeny of $D$. pulex inferred from $18 S$ gene sequences as a consensus tree formed from trees constructed using maximum likelihood (ML), and neighbor-joining (NJ), Bayesian inference (BI) methods.

doi:10.1371/journal.pone.0152436.g004 


\section{Tests on the genetic difference of $D$. pulex from the middle and lower reaches of Yangtze River}

Based on the sequences of $16 \mathrm{~S}$ rDNA, COI gene, and $18 \mathrm{~S}$ gene, the genetic differences of D. pulex were analyzed within lakes and between lakes in the middle and lower reaches of Yangtze River. Mann-Whitney Test showed that the genetic differences of the $D$. pulex between within-lakes and between-lakes were significant (COI gene: $\mathrm{Z}=-3.172, P=0.002 ; 16 \mathrm{~S}$ rDN: $\mathrm{Z}=-3.096$, $P=0.002 ; 18 S$ gene: $Z=-3.378, P=0.001)$. Two-Sample Kolmogorov-Smirnov test showed the significant differences in both within-lakes and between-lakes ( $C O I$ gene: $Z=1.789, P=0.003$; $16 S$ rDNA: $Z=2.012, P=0.001 ; 18 S$ gene: $Z=2.012, P=0.001)$. The box diagram of $D$. pulex genetic diversity also demonstrated significant differences between within-lakes and betweenlakes based on the sequences of $16 \mathrm{~S} \mathrm{rDNA}, \mathrm{COI}$ gene, and $18 \mathrm{~S}$ gene (Fig 5), which indicate that the genetic structure of $D$. pulex exhibiting differentiation among lakes.

Within lakes, the genetic difference of $D$. pulex from Lake Chaohu $(\mathrm{CH})$ was bigger than that of other lakes based on the sequences of COI gene and $18 S$ gene, and the genetic difference of $D$. pulex from Lake Nanyi (XC) was bigger than that of other lakes based on the sequences of COI gene and $16 S$ rDNA (Fig 5).

\section{Analysis of molecular variance}

Based on the sequences of $16 S \mathrm{rDNA}, \mathrm{COI}$ gene and $18 \mathrm{~S}$ gene, the Molecular Variance of $D$. pulex were analyzed to calculate the population genetics for each site in the middle and lower reaches of Yangtze River. The result suggested that the pairwise differences were greater among populations than within populations based on the sequences of $16 \mathrm{~S}$ rDNA, COI gene and $18 S$ gene (Table 5). The AMOVA test showed that there were significant differences between two groups (middle reach and lower reach) based on $16 \mathrm{~S}$ rDNA and COI gene (Table 6).

\section{Discussion}

For $16 S$ rDNA and COI gene sequences of $D$. pulex from 10 water bodies located in the middle and lower reaches of Yangtze river, the $\mathrm{A}+\mathrm{T}$ content $(65.4 \%$ and $58.4 \%$, respectively) was significantly higher than the $\mathrm{G}+\mathrm{C}$ content (34.6\% and $41.6 \%$, respectively). Those results were consistent with the higher $\mathrm{A}$ and $\mathrm{T}$ contents among invertebrates [37-38]. Moreover, the overall transition/transversion bias of $D$. pulex based on COI gene (8) was obviously higher than those based on the $16 S$ rDNA (1.09) and $18 S$ gene (2.5).

Based on the genetic variation of the $16 S$ rDNA and COI genes, the D. pulex from 10 water bodies located in the middle and lower reaches of the Yangtze River evolved into two branches, as shown in the phylogenetic trees. One branch included the D. pulex from Lake Donghu in Hubei Province, as well as Lake Shengjin, Lake Nanyi, Lake Chaohu, and Guohe River in Anhui Province. The other branch included D. pulex from a pond in Shanghai City, Lake Taihu and Lake Hongze in Jiangsu Province, as well as Lake Qianlong, a pond, Lake Chaohu, and Lake Nanyi in Anhui Province. The D. pulex from Lake Chaohu and Lake Nanyi in Anhui province were present in both branches, which coincided with its geographical distribution in the middle and lower reaches of the Yangtze River. Based on the sequences of $16 S \mathrm{rDNA}, \mathrm{COI}$ gene and $18 S$ gene of $D$. pulex, the AMOVA test also showed that there all were greater genetic differences among lakes than within lakes in the middle and lower reaches of the Yangtze River. And significant genetic differences between two groups (middle reach and lower reach) were showed based on $16 S$ rDNA and COI gene of $D$. pulex. Then the genetic distances of $D$. pulex from 10 water bodies located in the middle and lower reaches of Yangtze River showed minimal divergence based on $16 S$ rDNA (0\%-1.0\%), COI gene (0\%-1.7\%), and $18 S$ gene $(0 \%-$ 


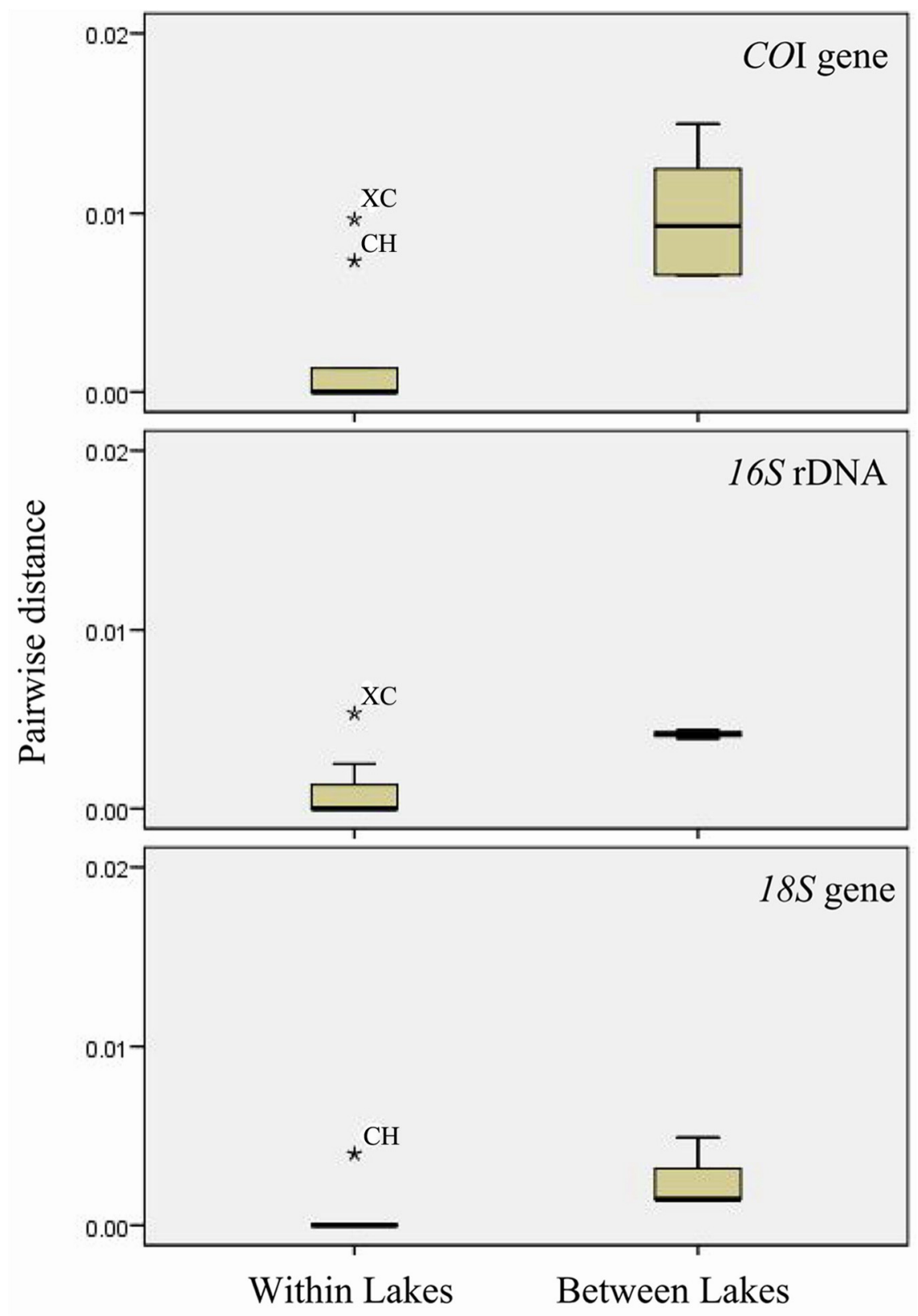

Fig 5. Box diagram of D. pulex genetic diversity within-lakes and between-lakes (XC: Lake Nanyi; $\mathrm{CH}$ : Lake Chaohu).

doi:10.1371/journal.pone.0152436.g005

$0.9 \%)$, and all those differences were within the scope $(<5 \%)$ of species $[16,33,39]$. These findings implied that the $D$. pulex from the lakes located in the middle and lower reaches of Yangtze River region should belong to the same species. In addition to further geographical distance, other environmental conditions, such as different climate, altitude, and fishery in the middle and lower reaches of the Yangtze River, may be important factors to the evolution of $D$. pulex.

Compared with the D. pulex from Canada (AF117817, GQ343275) [40, 41] and Russia (JN874605, JN874606, and JN874607) [42], the genetic distances of $D$. pulex from 10 water bodies located in the middle and lower reaches of the Yangtze River reached 9.1\%-9.6\% based 
Table 5. Analysis of molecular variance (AMOVA) based on the $16 S$ rDNA, COI gene and $18 S$ gene sequences of $D$. pulex in the middle and lower reaches of Yangtze River.

\begin{tabular}{|c|c|c|c|c|c|c|c|}
\hline & Source of variation & Degrees of freedom & Sum of squares & Variance components & Variation (\%) & $p$-value & FST \\
\hline $16 S$ rDNA & Among population & 9 & 158.425 & $3.63403 \mathrm{Va}$ & 59.23 & & \\
\hline $16 S$ rDNA & Within population & 30 & 92.000 & $2.56667 \mathrm{Vb}$ & 40.77 & & \\
\hline $16 S$ rDNA & Total & 39 & 250.425 & 6.20069 & & 0.000 & 0.59234 \\
\hline COI gene & Among population & 9 & 124.850 & $2.90139 \mathrm{Va}$ & 56.14 & & \\
\hline COl gene & Within population & 30 & 68.000 & $2.26667 \mathrm{Vb}$ & 43.86 & & \\
\hline COI gene & Total & 39 & 192.850 & 5.16806 & & 0.000 & 0.56141 \\
\hline $18 S$ gene & Among population & 9 & 300.275 & $8.12222 \mathrm{Va}$ & 90.27 & & \\
\hline $18 S$ gene & Within population & 30 & 26.250 & $0.87500 \mathrm{Vb}$ & 9.73 & & \\
\hline $18 S$ gene & Total & 39 & 326.525 & 8.99722 & & 0.000 & 0.90275 \\
\hline
\end{tabular}

Note: populations were evaluated as a single group. Each lake was as a population.

doi:10.1371/journal.pone.0152436.t005

on $16 S$ rDNA sequence. The genetic differences was obviously beyond the scope of a species $(<5 \%)[16,33,39]$, and it indicated the presence of subspecies. Long-term geographic isolation may be the main reason for the evolution of the D. pulex in China and other countries. In addition, the average genetic distance between the D. pulex in Japan (GU595190) and the D. pulex in China reached $10.5 \%$ based on the COI gene sequence. The genetic distance was in the scope of the Daphnia complex (5\%-14\%). Thus, compared with the D. pulex (GU595190) in Japan, the $D$. pulex from China should belong to different subspecies or the D. pulex complexes [6, 16, $33,43]$. On the other hand, the genetic distance of the D. pulex (GU595192) in Japan and in China was below $5 \%$. We speculated that the D. pulex had same ancestor and evolved to different directions by natural selection in Japan and China. Although the average genetic distances of the D. pulex from Canada (AF014011) and from China were small (0.45\%-0.64\%) based on

Table 6. Analysis of molecular variance (AMOVA) based on the 16S rDNA and COI gene sequences of $D$. pulex about the two groups (middle reach vs. lower reach) in the Yangtze River.

\begin{tabular}{|c|c|c|c|c|c|c|c|}
\hline & Source of variation & $\begin{array}{l}\text { Degrees of } \\
\text { freedom }\end{array}$ & $\begin{array}{l}\text { Sum of } \\
\text { squares }\end{array}$ & $\begin{array}{l}\text { Variance } \\
\text { components }\end{array}$ & $\begin{array}{l}\text { Variation } \\
(\%)\end{array}$ & FSC/ FST & $p$-value \\
\hline $\begin{array}{l}16 S \\
\text { rDNA }\end{array}$ & Among groups & 1 & 34.240 & $1.29190 \mathrm{Va}$ & 20.22 & & \\
\hline $\begin{array}{l}16 S \\
\text { rDNA }\end{array}$ & $\begin{array}{l}\text { Among populations within } \\
\text { groups }\end{array}$ & 6 & 89.167 & $3.25434 \mathrm{Vb}$ & 50.93 & & \\
\hline $\begin{array}{l}16 S \\
\text { rDNA }\end{array}$ & Within populations & 24 & 44.250 & $1.84375 \mathrm{Vc}$ & 28.85 & & \\
\hline $\begin{array}{l}16 S \\
\text { rDNA }\end{array}$ & Total & 31 & 167.656 & 6.38999 & & $\begin{array}{l}0.63834 / \\
0.71146\end{array}$ & $\begin{array}{l}0.000 / \\
0.000\end{array}$ \\
\hline $\begin{array}{l}\text { COI } \\
\text { gene }\end{array}$ & Among groups & 1 & 48.385 & $2.79421 \mathrm{Va}$ & 54.88 & & \\
\hline $\begin{array}{l}\text { COI } \\
\text { gene }\end{array}$ & $\begin{array}{l}\text { Among populations within } \\
\text { groups }\end{array}$ & 6 & 38.833 & $1.39149 \mathrm{Vb}$ & 27.33 & & \\
\hline $\begin{array}{l}\text { COI } \\
\text { gene }\end{array}$ & Within populations & 24 & 21.750 & $0.90625 \mathrm{Vc}$ & 17.80 & & \\
\hline $\begin{array}{l}\mathrm{COI} \\
\text { gene }\end{array}$ & Total & 31 & 108.969 & 5.09196 & & $\begin{array}{l}0.60559 / \\
0.82202\end{array}$ & $\begin{array}{l}0.000 / \\
0.000\end{array}$ \\
\hline
\end{tabular}

Note: populations were evaluated as two groups (middle reach vs. lower reach) except Lake Chaohu and Lake Nanyi. Each lake was regarded as a population.

doi:10.1371/journal.pone.0152436.t006 
the $18 S$ gene sequence, the difference was evident. In general, the evolutionary divergences of the D. pulex among different lakes located in the middle and lower reaches of the Yangtze River were minimal. However, the evolutionary divergence was relatively high compared with that of other countries. The global molecular phylogeny of $D$. pulex needs to be further studied and discussed.

The intercontinental phylogeny of the $D$. pulex complex is extremely complicated. Based on the sequences of the mitochondrial dehydrogenase NADH 5 subunit and COI genes of $398 D$. pulex individuals from five continents, Crease et al. (2012) concluded that 11 lineages of the $D$. pulex complex can be observed worldwide [29]. By studying the D. pulex complex from 12 Bolivian high-altitude lakes, the D. pulicaria group in North America was found to originate in South America, whereas these South American water fleas originated through reciprocal hybridization between different sexually reproducing parental lineages [44]. In the present study, based on the $16 \mathrm{~S}$ rDNA sequence, the average genetic distances of the $D$. pulex from China and the D. parvula and the D. obtusa from Canada were $7.3 \%$ and $8.2 \%$, respectively. Their differences belong to the scope of the D. pulex complex (5\%-14\%) [16, 29-33, 45]. Benzie (2005) hypothesized that the main factor that led to the formation of species complexes between the $D$. pulex, D. pulicaria, and D. middendorffiana was their long-term coexistence in the same habitat, which resulted in the occurrence of interspecies complexes $[6,16]$. In the middle and lower reaches of the Yangtze River in China, the coexistence of D. pulex, D. galeata, and D. similoides was common in some lakes (e.g. Lake Donghu, Lake Taihu, and Lake Chaohu) [8-10]. Thus, the existence of species complexes among Daphnia species in these Chinese lakes was possible, and further investigation is needed.

\section{Author Contributions}

Conceived and designed the experiments: W-PW D-GD KZ. Performed the experiments: WPW KZ S-XP X-XX. Analyzed the data: W-PW D-GD Y-NZ. Contributed reagents/materials/ analysis tools: W-PW D-GD KZ Y-NZ. Wrote the paper: W-PW D-GD Y-NZ KZ.

\section{References}

1. Forro L, Korovchinsky NM, Kotov AA, Petrusek A. Global diversity of cladocerans (Cladocera; Crustacea)in freshwater. Hydrobiologia. 2008; 595: 177-184.

2. Bunioto TC, Arcifa MS. Effects of food limitation and temperature on cladocerans from a tropical Brazilian lake. Aquatic Ecology. 2007; 41: 569-578.

3. Liady MND, Tangou TT, Fiogbe ED, Cauchie HM, Vasel JL. About the interest of a zooplankton compartment in pond systems: methodology to study the growth kinetic of Daphnia pulex on Scenedesmus sp. Water Science \& Technology. 2015; 71(10): 1436-1443.

4. Oosterhout FV, Lürling $M$. The effect of phosphorus binding clay (Phoslock) in mitigating cyanobacterial nuisance: a laboratory study on the effects on water quality variables and plankton. Hydrobiologia. 2013; 710(1): 267-277.

5. Jiang XZ, Du NS. Fauna sinica: crustacean, freshwater cladocera. Science Press;1979.

6. Benzie JAH. The genus Daphnia (including Daphniopsis) (Anomopoda: Daphniidae).Leiden;2005.

7. Zhang L, Fan CX, Wang JJ, Chen YW, Jiang JH. Nitrogen and phosphorus forms and release risks of lake sediments from the middle and lower reaches of the Yangtze River. Journal of Lake Sciences. 2007; 20(3): 263-270.

8. Lu M, Xie P. Studies on the structure of crustacean zooplankton in Houhu region of Lake Donghu, Wuhan. Acta Hydrobiologica Sinica. 2008; 26(2): 123-129.

9. Chen WM, Qin $B Q$. The zooplankton distribution during winter and early spring and its environmental effects in Meiliang Bay, Taihu Lake. Journal of Lake Sciences. 1998; 10(4): 10-16.

10. Deng DG, Xie P, Zhou Q, Yang H, Guo LG, Geng H. Field and experimental studies on the combined impacts of cyanobacterial blooms and small algae on crustacean zooplankton in a large, eutrophic subtropical Chinese lake. Limnology. 2008; 9: 1-11. 
11. Stenderup JT, Olesen J, Glenner H. Molecular phylogeny of the Branchiopoda (Crustacea) -multiple approaches suggest a 'diplostracan' ancestry of the Notostraca. Molecular Phylogenetics and Evolution. 2006; 41(1): 182-194. PMID: 16904916

12. Sharma $P$, Kotov AA. Molecular approach to identify sibling species of the Ceriodaphnia cornuta complex (Cladocera: Daphniidae) from Australia with notes on the continental endemism of this group. Zootaxa. 2013; 3702(1): 79-89.

13. Jeffry NW, Eliasi-gutierrez M, Adamowicz SJ. Species diversity and phylogeographical affinities of the Branchiopoda (Crustacea) of Churchill, Manitoba, Canada. PLoS One. 2011; 6 (5): E18364. doi: 10. 1371/journal.pone.0018364 PMID: 21610864

14. Elias-gutierrez M, Jeronimo FM, Ivanova NV, Valdez-moreno M, Hebert PDN. DNA barcodes for cladocera and copepoda from Mexico and Guatemala, highlights and new discoveries. Zootaxa. 2008; 1839: 31-42.

15. Richter S, Olesen J, Wheeler WC. Phylogeny of Branchiopoda (Crustacea) based on a combined analysis of morphological data and six molecular loci. Cladistics. 2007; 23(4): 301-336.

16. Taylor DJ, Finston TL, Hebert PDN. Biogeography of a widespread freshwater crustacean: pseudocongruence and cryptic endemism in the north American Daphnia laevis complex. Evolution. 1998; 52(6): 1648-1670.

17. Dai YJ, Liu P, Gao BQ, Li J,Wang QY. Sequence analysis of mitochondrial $16 S$ rRNA and COI gene fragments of four wild populations of Portunus trituberculatus. Periodical of Ocean University of China. 2010; 40(3): 54-60.

18. Kotov AA, Ishida S, Taylor DJ. Revision of the genus BosminaBaird, 1845 (Cladocera: Bosminidae), based on evidence from male morphological characters and molecular phylogenies. Zoological Journal of Linnean Society. 2009; 156 (1): 1-51.

19. Huang XN, Shi XL,Kotov AA,Gu FK. Confirmation through penetic analysis of the existence of many local phyloclades of the genus Simocephalus (Crustacea, Cladocera) in China. PLoS One. 2014; 9 (11): e112808. doi: 10.1371/journal.pone.0112808 PMID: 25393020

20. Xu S, Hebert PD, Kotov AA, Crestescu ME. The noncosmopolitanism paradigm of freshwater zooplankton: insights from the global phylogeography of the predatory cladoceran Polyphemus pediculus (linnaeus, 1761) (Crustacea,Onychopoda). Molecular Ecology. 2009; 18(24): 5161-5179. doi: 10.1111/j. 1365-294X.2009.04422.x PMID: 19912535

21. Dewaard JR, Sacherova V, Cristescu MEA, Remigiod EA, Creasea TJ, Hebertal PDN. Probing the relationships of the branchiopod crustaceans. Molecular Phylogenetics and Evolution. 2006; 39(2): 491502. PMID: 16406819

22. Adamowicz SJ, Hebert PDN, Marinone MC. Species diversity and endemism in the Daphnia of Argentina: a genetic investigation. Zoological Journal of the Linnean Society. 2004. 140, 171-205.

23. Hebert PDN, Witt JDS, Adamowicz SJ. Phylogeographical patterning in Daphnia ambigua: regional divergence and intercontinental cohesion. Limnol. Oceanogr., 2003. 48, 261-268.

24. Mergeay J, Aguilera X, Declerck S, Petrusek A, Huyse T, De Meester L. The genetic legacy of polyploid Bolivian Daphnia: the tropical Andes as a source for the North and South America D. pulicaria complex. Molecular Ecology, 2008. 17,1789-1800. doi: 10.1111/j.1365-294X.2007.03679.x PMID: 18284570

25. Ishida S, Taylor DJ. 2007. Quaternary diversification in a sexual Holarctic zooplankter, Daphnia galeata. Molecular Ecology, 16, 569-582. PMID: 17257114

26. John KC, Michael EP, Donald GW, Kelley T, Abraham T, Todd HO, et al. The ecoresponsive genome of Daphnia pulex. Science. 2011; 331(6017): 555-561. doi: 10.1126/science.1197761 PMID: 21292972

27. Toyota K, Miyakawa H, Yamaguchi K, Shigenobu S, Ogino Y, Tatarazako N, et al. NMDA receptor activation upstream of methyl farnesoate signaling for short day-induced male offspring production in the water flea, Daphnia pulex. BMC Genomics. 2015; 16(1): 186.

28. Marková S, Dufresne F, Manca M, Kotlík P. Mitochondrial capture misleads about ecological speciation in the Daphnia pulex complex. PLoS One. 2013; 8 (7): e69497. doi: 10.1371/journal.pone.0069497 PMID: 23869244

29. Crease TJ, Omilian AR, Costanzo KS, Taylor DJ. Transcontinental phylogeography of the Daphnia pulex species complex. PLoS One. 2012; 7 (10): e46620. doi: 10.1371/journal.pone.0046620 PMID: 23056371

30. Weider LJ, Hobek A. Glacial refugia, haplotype distributions, and clonal richness of the Daphnia pulex complex in arctic Canada. Molecular Ecology. 2003; 12: 463-473. PMID: 12535096

31. Crease $T J$, Floyd R, Cristescu ME, Innes D. Evolutionary factors affecting lactate dehydrogenase $A$ and B variation in the Daphnia pulex species complex. BMC evolutionary biology. 2011; 11(1): 212. 
32. Ambrose CD, Crease TJ. Evolution of the nuclear ribosomal DNA intergenic spacer in four species of the Daphnia pulex complex. BMC genetics, 2011; 12(1): 13.

33. Adamowicz SJ, Petrusek A, Colbourne JK, Hebertd PDN, Witt JDS. The scale of divergence: a phylogenetic appraisal of intercontinental allopatric speciation in a passively dispersed freshwater zooplankton genus. Molecular Phylogenetics and Evolution. 2009; 50(3): 423-436. doi: 10.1016/j.ympev.2008. 11.026 PMID: 19124080

34. Bouchon D, Souty-Grosser C, Raimond R. Mitochondrial DNA variation and markers of species identity in two penaeid shrimp species: Penaeus monodon Fabricius and $P$. japonicus Bate. Aquaculture. 1994; 127(2): 131-144.

35. Xu M, Zhang HJ, Deng DG, Wang WP, Zhang XL, Zha LS. Phylogenetic relationship and taxonomic status of four Daphnia species based on $16 S$ rDNA and CO sequence. Acta Hydrobiologica Sinica. 2014; 38(6): 1040-1046.

36. Excoffier L, Lischer HEL. Arlequin suite ver 3.5: A new series of programs to perform population genetics analyses under Linux and Windows. Molecular Ecology Resources, 2010, 10: 64-567.

37. Anderon FE. Phylogeny and historical biogeography of the loliginid squids (Mollusca: Cephalopoda) based on mitochondrial DNA sequence data. Molecular Phylogenetics and Evolution. 2000; 15(2): 191-214. PMID: 10837151

38. Gao TX, Zhang XM, Yoshizaki G. Study on mitochondrial DNA sequences of Japanese mitten crab, Eriocheir japonica.12S rRNA. Journal of Ocean University of Qingdao. 2000; 30(1): 43-47.

39. Miner BE, Knapp RA, Colbourne JK. Evolutionary history of alpine and subalpine Daphnia in western North America. Freshwater Biology. 2013; 58(7): 1512-1522.

40. Crease TJ. The complete sequence of the mitochondrial genome of Daphnia pulex Cladocera: Crustacea). Gene. 1999; 233(1): 89-99.

41. Briski E, Cristescu ME, Bailey SA, Maclsaac HJ. Use of DNA barcoding to detect invertebrate invasive species from diapausing eggs. Biological Invasions. 2011; 13(6): 1325-1340.

42. Zuykova El, Bochkarev NA, Katokhin AV. Molecular genetic identification and phylogeny of Daphnia species (Crustacea, Cladocera) from water bodies of the Lake Chany basin. Russian Journal of Genetics. 2013; 49(2): 206-213.

43. Kotov AA, Taylor DJ. A new African lineage of the Daphnia obtusa group (Cladocera: Daphniidae) disrupts continental vicariance patterns. Journal of Plankton Research. 2010; 32(6): 937-949.

44. Mergeay J, Aguilera X, Declerck S, Petrusek A, Huyse T, De Meester L. The genetic legacy of polyploid Bolivian Daphnia: the tropical Andes as a source for the North and South American D. pulicaria complex. Molecular Ecology. 2008; 17(7): 1789-1800. doi: 10.1111/j.1365-294X.2007.03679.x PMID: 18284570

45. Gewin V. Functional genomics thickens the biological plot. PLoS biology. 2005; 3(6): 949.

46. Colbourne JK, Wilson CC, Hebert PDN. The systematics of Australian Daphnia and Daphniopsis (Crustacea: Cladocera): a shared phylogenetic history transformed by habitat-specific rates of evolution. Biological Journal of the Linnean Society. 2006; 89(3): 469-488.

47. Geng XX, Zhang L, Xu M, Deng DG, Zhang HJ. PCR amplication and sequence analysis of COI genes and their flanking regions of mitochondrial DNA from three Daphnia species. Journal of Nanjing Agricultural University. 2014; 37(3): 44-50.

48. Prosser S, Martinez-Arce A, Elias-Gutierrez M. A new set of primers for COI amplification from freshwater microcrustaceans. Molecular Ecology Resources. 2013; 13(6): 1151-1155. doi: 10.1111/17550998.12132 PMID: 23795700

49. McTaggart SJ, Crease TJ. Selection on the structural stability of a ribosomal RNA expansion segment in Daphnia obtusa. Molecular Biology and Evolution. 2005; 22(5): 1309-1319. PMID: 15746016

50. Damme KV, Shiel RJ, Dumont HJ. Notothrix halsei gen. n., sp. n., represent tative of a new family of freshwater cladocerans (Branchiopoda, Anomopoda) from SW Australia, with a discussion of ancestral traits and a preliminary molecular phylogeny of the order. Zoologica Scripta. 2007; 36(5): 465-487.

51. Spears T, Abele LG. Branchiopod monophly and interordinal phylogeny inferred from $18 S$ Ribosomal DNA. Journal of Crustacean Biology. 2000; 20 (1): 1-24. 